TRANS $\cdot \mathrm{N}^{\mathrm{O}} 5 \cdot 2 \mathrm{OOT}$

ARTICULOS $\cdot 9-21$
Recent translation theories and descriptive translation studies emphasize the power of translated texts as shaping forces in literary canons as well as the ideological appropriation which the works of translators conceal. French cultural ascendancy in eighteenth and nineteenth century Spain is widely acknowledged, especially in the case of the reception of English, German and Russian literature. However, apart from early research in the field of literary comparativism, French mediation in translation has received inadequate attention in Spanish speaking countries. In this article we intend to analyse the ideological manipulation traced in three Hispanic versions of W.M. Thackeray's Vonity Foir (1847-48) published between 1860 and 1930, which used the 1853 French translation of the Victorian classic as their source text. Particular consideration will be given to those conflictual translated texts concerning the sexual role of the main male and female characters which wipe out the ambiguity of the original work.

\title{
Ideological Constraints and French Mediation in Hispanic Translated Texts: 1860-1930
}

Las más recientes corrientes traductológicas y los estudios descriptivos de la traducción subrayan el poder de los textos traducidos para moldear cánones literarios asi como la apropiación ideológica que encierra la obra de los traductores. Durante los siglos XVIII Y XIX, el enorme influjo de la cultura francesa en la española es un hecho indiscutible, sobre todo en lo que respecta a la recepción de literatura inglesa, alemana y rusa. Sin embargo, si exceptuamos los tempranos trabajos de investigación realizados en el campo de la literatura comparada, el papel fundamental de la mediación cultural francesa en los paises de habla hispana ha recibido muy poca atención hasta el momento. En este articulo, pretendemos analizar la manipulación ideológica localizada en las tres primeras versiones hispónicas de La feria de las vanidades (W.M. Thackeray:1847-48), publicadas entre 1860 y 1930, y cuyo texto original fue la traducción francesa del clásico victoriono (1853). En concreto, nuestro estudio se centrará en aquellos textos traducidos conflictivos que reflejan el rol sexual de los principales personajes obra original 


\section{IN'TRODUCTION}

A translator is a privileged reader because «as processor of texts, [he/she] filters the text world of the source text through his/her own worldview/ideology, with differing results» ${ }^{2}$. Translators and their translations are seldom capable of complete impartiality in their appropriation of source texts. In this sense, "whether presumptuous or subservient, they are indispensable links (...) they not only cross boundaries, they also simultaneously set them and break them ${ }^{3}$.

Since its publication in twenty monthly instalments between January I847 and July I848, William M. Thackeray's Vanity Fair ( $A$ Novel without a Hero), together with Jane Eyre, Wuthering Heights, Bleak House and Middlemarch, has traditionally occupied a central position in the development of the unsettled Victorian literary canon ${ }^{4}$. An outstanding feature in Vanity Fair, that has called the attention of many scholars, is its ironic, cynical narrative voice that establishes a complex approach to the main male and female characters and elicits a variety of responses from its readers'. Early French and Hispanic translations of Vanity

- This article is based on a paper delivered at the 6 th Conference for the Study of European Idcas (ISSEI) held at the University of I-Iaifa (Isracl), I6-21 August I998. I am grateful to the participants of the workshop programme "Iranslated 'Texts and the Rewriting of Sexual Stereotypesw for their comments.

Hatim, B. \& I. Mison. The Translator as Communiator. London: Routledge, r 097 , p. 147.

; Gaddis Rose, M. Transhation and Literary Criticism. Translation as Analysis. Manchester: St. Jerome, 1997, p. 2.

${ }_{4}$ As many other classic novels, Vanity $F$ air is open to many interpretations: a historical study similar to Tolstoy's War and Peace, a humoristic story told in the tradition of the author's master. Henry Fielding; a parody of the silverfork and Newgate tales; a bitter satire of the Regency period; a brilliant exploration of female psychology; a pioneering recognition of masculine limitations, etc. (See Olmstead, J.C. Thackeray and his 'Jwentieth Cenlury Critios. An Annotated Bibliogriphy ro00-1075. New York: Garland, I997 and Shillingsburg, P. "Thackeray Studies: r983-1992", Dick chs Studios Annuml, 23 [1905] pp. 303-35).

Clarke, M. M. Thackeny ind Women. Dekalb: Northern Illinois UI, 1095.
Fair, taken as diverse interpretations of the Thackerayan universe, reflect the power of translated texts to challenge the illusion of faithfulness and to develop processes of ideological rewriting of the source text.

\section{EARLY HISPANIC TRANSLATIONS OF VANITY FAIR: THE FRENCH MEDIATION}

Vanity Fair was first translated into French in 1853. It is one of the earliest European versions after the texts published in Sweden and Denmark (I849), Russia (I850) and Hungary (I853). The translation was sponsored by Hachette, one of the most prominent publishing houses, and translated by Georges Guiffrey (I827-87); a Parisian lawyer and politician who held, among other posts, in the highest ranks of the State administration, that of General Governor of the Department of the Hautes-Alpes. He was elected senator for the same constituency in I879 and spent his final years writing history books on French Renaissance and Baroque. Even if there are other versions of William $M$. Thackeray's novel, Georges Guiffrey's translation can be considered to be the French canonical text that has been present in the national literary polysystem for more than one hundred and forty years. Moreover, it was selected by Sylvère Monod in 1994 for the latest edition of the Victorian classic, that can be bought at any local bookshop in Francé.

The first translation of Vanity Fair into

"For more detailed information on the reception of W.M.' lhackeray in Eastern Europe see Pantickova, L. "Thackeray in Czcchosloviakia (with al Glance at Other Slavonic Countries)», Studies in the Novel, XII- I \& 2 ( (1981), pp). 197-207, and Harper, K.E. Bradford \& Booth, A. «Russian Translations of Nincteenth Century English Fiction", Nincteenth Century fiction, 8 (I053), pp. I88-97.

There alre at least three more french versions of Vinity Fair translated by Henri Duclos de la Maldère (laris: Del grave, 1938), Jeanne L. Richard (Paris: Éditions du Dauphin, 1947) and Eugène Rocart (Brussels: La Boètic, 1948).

A complete biography of Georges Guiftrey can be found in Vapeilralu, M. Dichonnaire Universel des Con- 
Spanish was not published in Europe, but in Mexico in 1860. A careful exam of the cover, the backcover and the title page of the volume shows no trace of the translator's name. However, page one includes a footnote that informs the reader that La feria de las vanidades is the second issue of a series called "Colección de Novelas» and that the printer was «Andrade $y$ Escalante». In the second half of the nineteenth century, the surname Andrade was to be related to the important Mexican editor José María Andrade, who was born in the village of Apán in 1807 and died in Mexico City in 1883. At the Zócalo Square, he owned a bookshop where important celebrities of those years met and discussed the latest literary fashions recently arrived from Europe. Andrade had to sell his splendid personal library to Maximilian (the Austrian Emperor brought by Napoleon to the Mexican throne) who by that time had in mind the project of building an Imperial Library in the capital of his kingdom. After he was shot most of the books were sent to Europe, where they were sold in public auction? ${ }^{7}$.

The first Spanish translation of Vanity Fair

temporains. Paris: Hachette, 1880 ; an extensive account of the Victorian author in France is given by S. Monod in her remarkable article entitled: "Thackerny's French Dressers", Studies in the Novd, XII-1 \& 2 (1981), pp. 197-207.

To the best of our knowledge, there is a copy of this translation at The British Library. Recent communication with the most important libraries of Mexico, such as the National Library or that of El Colegio de México has not proved successful in finding more copies. Other Latin American translations include those versions made in Argentina by Javier Frías (1941) and Hugo L. Silvestre (1946).

See Diccionario Enciclopêdico de México (1989) for a longer biography of Andrade. After the fall of Maximilian's empire the library was taken to Europe by Father Agustín Fischer: «y al fin la remató en 1860 en Leipzig. Fischer agregó a ese envío la selecta colección mexicana que él mismo habia formado, que vendió a libreros de Londres en el mismo año (...) Herbert Howe Bancroft, el historiador estadounidense que se ocupó de la historia de América, hombre de gran fortuna, logró adquirir más de 3.000 volúmenes de la venta de la biblioteca de José María de Andrade, más de r.ooo libros de la de José Fernando Ramirez, y unas 8.000 obras que adquirió en México en was published in Madrid approximately in 1925. It was launched through a fortnight publication, inspired by the world famous novelist Vicente Blasco-Ibánez, called "La Novela Ilustrada», which mainly included foreign writers such as Wilkie Collins, Guy de Maupassant, Conan Doyle, Charles Dickens, Prospère Merimée, George Sand, Leon Tolstoy, etc. This series is a perfect example of high circulation cheap volumes directed to low-middle-class and working-class readers published by a small company that paid poor salaries to its writers and translators.

Pedro González-Blanco ( $1877^{-1962)}$, the translator of the first Spanish version of Vanity Fair, was a journalist and an active member of the poetic avant-garde and bohemian circles in the first years of this century. In 1908 he travelled to South America, where he was continuously be involved with revolutionary movements in Guatemala, Paraguay and Mexico. Forced into exile after the Spanish civil war because of his involvement with freemasonry organizations, he lived in Mexico for a long time. In this final part of his life he was hired as a hack-writer by different dictators, such as Trujillo in Santo Domingo and Perón in Argentina.

The second Spanish translation of Vanity Fair was edited in Barcelona in 1930 by the Catalan publisher Joaquín Sopena, whose very important printing workshop was confiscated in the first days of the Spanish Civil War by

I883. Tan copiosa biblioteca de más de 40.000 volúmenes y 12.00o manuscritos la instaló Bancroft en un edicifio especial de Berkeley, San Francisco, California, y a su muertc pasó a enriquecer la de la Universidad de ese lugar» (Martínez, J.L. El libro en Hispanoamerica. Origen y desarrollo. Madrid: FGSR-Ediciones Pirámide, 1984, p.80).

* See Rodríguez Espinosa, M. "Traducción y aventura: Pedro González-Blanco (1877-1962), traductor de lia Generación del 98", Vega Cernuda, M.A. (ed.). La traduccion en torno al 08 . Madrid: Instituto Universitario de Lenguas Modernas y Traductores-Universidad Complutense de Madrid, 1998, pp. $225^{-} 33^{2}$ 
the Communist Party and used by its publishing house «Nuestro Pueblo» for propaganda purposes. The company's major commercial success was the series called "Biblioteca de Grandes Novelas» that launched a vast collection of Spanish, French, British and North American novels at cheap prices. After the Spanish Civil War, Sopena became one of the most important publishing houses, with branches in most Latin American countries ${ }^{9}$.

This text was translated by someone called Gregorio Lafuerza. It has been impossible to find out who hides behind this nom-de-plume, and the only certain information about him is that he also translated for Sopena a few French authors, such as Xavier Aymon de Montepin, Alexandre Dumas, Victor Hugo, Stendhal and Jules Verne, as well as English speaking novelists such as William Frederick Cody and Charles Dickens, among others. Gregorio Lafuerza's translation of Vanity Fair, and most of the other novels of the same series, were printed for the last time in 1975 and are still available at many second-hand bookshops.

The Mexican translation (I860), the first Spanish translation (I925?) and to a large extent the second (1930) used the French version rendered by Georges Guiffrey in 1853 as their source text. Harald Kittel and Armin Paul Frank define indirectness as a,

\footnotetext{
"La incautación fue [la] fortuna [de Joaquín Sopenal, pues al terminar la contienda se encontró con los almacenes lienos de papel, del que se apropió como compensación. Frente a la descapitalización de otros empresarios, él experimentó una hipercapitalización. Su actividad principal era la imprenta. Imprimia las guias telefónicas de España sin competencias gracias al subterfugio de conservar la composición en plomo, por lo que cada nueva edición sólo tenía que actualizar algunos cambios e introducir los nuevos datos. No obstante, su editorial hacia un elevado volumen de ventas con novelas grandes, diccionarios y enciclopedias, cuyas reediciones facilitaba su taller (Sobrino, H.E. Gentes del libro. Autores, Editores y Bibliotecarios 19391999. Madrid: Gredos, I999, p.239).
}

somewhat unspecific and potentially misleading attribute for a translatorial phenomenon more accurately described in German as 'Übersctzung aus zweiter Hand' (...) applicable to any translation based on a source (or sources) which is itself a translation into a language other than the language of the original, or the target language ${ }^{\text {to }}$.

This phenomenon has very frequently occurred in different literary polysystems. In the case of the emergence of a national literature in Mexico, it is another component of the heavy predominance of French culture in Latin American countries after their independence from the Spanish Empire.

In the case of the Spanish polysystem, between 1840 and 1920, French booksellers established in Spain, or French bookshops which had opened branches in the Peninsula, played an influential role in the supply of translations or adaptations of European Literature". Examining this issue with more detail, José Fernández Montesinos, in his bibliography of Spanish translations of English novels, describes the national publishing industry as being totally under French control at the end of the eighteenth and nine-

to Kittel, I- \& A.P. Frank (eds.). Interculturality and the Historical Study of Literary Translations. Berlin: Erich Schmidt, I991, p. 3

" "En la historia cultural de España, el grado de dependencia respecto a Francia puede apreciarse, a nivel institucional, a partir de indicadores tales como el número de traducciones o adaptaciones, las importaciones de libros $y$ de impresos franceses en el sector de la librería y de la edición, el consumo de bienes culturales diversos, desde las noticias de París hasta los patrones de moda o la actividad más o menos auténtica de agentes de Francia, diplomáticos, corresponsales de prensa, libreros y otros intermediarios culturales", Botrel, J. F. Libros, prensa y lectura en la España del siglo XIX. Translated by David Torra Ferrer. Madrid: FGSR-Ediciones Pirámide, 1993, p.544).

Early studies of the powerful influence of French mediation in the translation of other European and North American classics can be traced in Englekirk, J.E. Eidgar Allan Poe in Hispanic Literature. New York: Instituto de las Españas en los Estados Unidos, I934, and Gregersen, $H$. Ibsen and Spain. Cambridge: Harvard UP, I939. 
teenth centuries. The influence, in most cases, was paramount, because in a few years it was to completely transform the book trade, the sales market and the reader's preferences $^{12}$. One of the first translations of Jonathan Swift's Gulliver's Travels (Los viajes de Gulliver, I793), the first Spanish translation of Samuel Richardson's lengthy epistolary novel Clarissa (I794-95), Henry Fielding's Tom Jones (1796), James Fenimore Cooper's The Pilot (El piloto, 1823-33), Daniel Defoë's Robinson Crusoe (1837) and Charles Dickens' The Chimes (La campana de los difuntos, 1847 ) are interesting examples which illustrate the powerful mediation of French source texts in the Spanish edition of English literature.

\section{THE TRANSI,ATOR'S VOICE IN TRANSLATED TEXTS}

None of the three first Hispanic editions of Vanity Fair include paratexts which explaining the translators' decisions during their work. This situation reinforces the paradoxical illusion that readers are confronted with William M. Thackeray's original source text, but also arises some questions about the translators' voice:

does the translator, the manual labour done disappear without textual trace, speaking entirely 'under erasure'? Can translators usurp the original voice and in the same move evacuate their own enunciatory space? Exactly whose voice comes to us when we read translated discourse?

\footnotetext{
12 Fernández Montesinos, J. Introdución a una bistoria de la novela en Lispaña del siglo XIX. (Seguido del esbozo de una bibliografía española de traducciones de novelas $1800-$ 1850). Madrid: Castalia, i960, p.23.

3 Hermans, 'I: "The Translator's Voice in Translated Narrative», Target, 8:1 (1996) pp. 23-48.
}

Lawrence Venuti uses the term invisibility to describe the marginal status of translators and of their work in contemporary Anglo-American culture, where translated texts are accepted by publishers, reviewers and readers if they are read fluently,

when the absence of any linguistic peculiarities make it transparent, giving the appearance that it reflects the foreign writer's personality or intention or the essential meaning of the foreign text - the appearance, in other words, that the translation is not in fact a translation, but the eoriginal $»^{\text {I4 }}$.

The ignorance of the translator's voice is historically connected with the normative concept of complete equivalence. Translation was a mechanical process and translated texts were categorized as good or bad, according to their faithfulness to the original text. Andre Lefevere believes that faithfulness is a translational strategy often inspired by a conservative ideology and,

to exalt it as the only strategy possible, or even allowable, is as utopian as it is futile. Translated texts as such can teach us much about the interaction of cultures and the manipulation of texts. These topics, in turn, may be of more interest to the world at large than our opinion as to whether a certain word has been "properly" translated or not ${ }^{25}$.

The first three Hispanic translations of Vanity Fair, under the close influence of the French version (1853), show how translators project their own image of the source text. In this case, the Mexican translation (I860) omits seven chapters of the novel and the first Span-

\footnotetext{
${ }_{4}$ Venuti, L. The Translator's Invisibility. London: Routledge, 1997, p.x.

is Lefevere, A. Translation, Rewriting, Es the Manipulation of Literary Fame. London: Routledge, 1992, p. 51
} 
ish text (1925?) sacrifices most of the lengthy performances of the author's implicit narrators. Furthermore, the four translated texts introduce meaningful changes by omitting and adding sentences which amount to an ideological rewriting of certain aspects of the main characters which had only been slightly hinted in the original novel ${ }^{16}$. If William M. Thackeray chose to interrogate patriarchal hierarchy through allusive, ambiguous language, the translated texts, on the one side, emphazised stereotyped images of male aggressiveness and sexual violence; on the other, conveyed a misogynist rewriting of those paragraphs referred to the two main female characters, Amelia Sedley and Rebecca Sharp.

\section{TRANSLATED TEXTS AND THE REWRITING OF MALE SEXUAL STEREOTYPES}

The main male characters of Vanity Fair are usually classified in two different age groups. The first one includes young men such as George Osborne (junior) and Rawdon Crawley. Older men such as Lord Steyne, Osborne (senior) and Sir Pitt Crawley belong to the second group. In the three first Hispanic translations, a tendency to render explicitly certain features of these characters that were only slightly implied in the source text can be noticed.

Both the Mexican translator (1860) and Pedro González-Blanco (1925?) follow closely the French text by inserting «el hijo rebelde» /

\footnotetext{
16 Feminist translation theory emphasizes the space of translation as conflictual and acknowledges the emotional and intellectual commitment of transiators and their work which «is able to trace out the networks of solidarity which brings translations into existence and to delineate the textures of the erotic and the ethical, the differential and the universal, that animate the work of linguistic transfern, Simon, S. Gender in Translation. Cultural Identity and the Politics of 7 ransmission. London: Routledge, 1997, p.162.
}

«fils rebelle» / [«tbe rebel son»], which emphasizes George Osborne's strong differences with his father. However, the Spanish version goes further in its ideological appropriation than the French source text in its rendering the sentence, «handling Mrs. Highflyer to her carriage after the play" as "acompañando al salir del teatro á la actriz High Flyer en su coche», which wipes out the ambiguous Thackerayan hint of the English text and changes it into an explicit reference to George Osborne's infidelity to his wife Amelia:

He's going pretty fast,' said the clerk. 'He's only married a week, and I saw him and some orher military chaps handling Mrs. Highflyer to her carriage after the play'(W.M. Thackeray, Vanity Fair, p.264).

Du reste, il mène la vie à grandes guides, reprit le clerc, voilà à peine une semaine quil est marié, et je l'ai vu l'autre jour avec d'autres individus de son régiment reconduire au sortir du théâtre mistress Highflyer à sa voiture (Georges Guiffrey, La foire aux vanités, 1853 , I: p.3I4).

Además, él lleva bucna vida, - continuó el notario; - apenas hace una semana que se casó y ya lo he visto el otro día con otros compañeros de regimiento acompañando al salir del teatro á la actriz High Flyer en su coche (Pedro González-Blanco, La feria de las vanidades, 1925 ?, p.152).

In a similar performance, Gregorio Lafuerza (I930) adds the sentence, "E1 desapego de éste, el desamor que te tenía era lo más me hacía sufrir» [What made me suffer was bis indifference and his lack of affection"]; in this way, the translator expands the translated text placing new references about young George Osborne in which those characteristics that describe him as a dissolute don Juan are underlined: 
'I knew it all along,' William said; 'but could I use that weapon against the poor fellow's memory? It was that which made me suffer so when you-' $(V F$, p.684 $)$.

- Todo lo que Rebeca te dijo lo sabía yo hace muchos años-, pero antes hubiese muerto de deseperación que utilizar un arma contra la memoria de mi pobre amigo. EI despego de éste, el desamor que te tenía era lo que más me hacia sufrir... (Gregorio Lafuerza 1930, p.653).

In the case of Rawdon Crawley, the Mexican version (1860), Pedro González-Blanco (1925?) and Gregorio Lafuerza (I930) stress some aspects of his personality related with his sexual behaviour, his role as a betrayed husband and the consequences of his violent temperament.

Considering the French translation (1853) as their source text, the Mexican translator and, with more richness in its lexical components, Gregorio Lafuerza add the sentence «by that abominable seducer and corrupter of youth", which exaggerates the powerful attraction and negative influence the officer has on young people:

She described with the most vivid minuteness the agonics of the country families whom he had ruined- the sons whom he had plunged into dishonour and poverty- the daughters whom he had inveigled into perdition ( $V F$, p.IgI).

Elle lui peignait, sous les couleurs les plus vives, le désespoir de toutes les familles de province qu'il avait ruinées, dont il avait précipité les fils dans le déshonneur et la pauvreté, ct poussć les filles à la honte et à l'infamie (I853, I: p. 218 ).

Le pintaba con vivos colores la descsperación de las familias que habia arruinado, precipitando á los hijos en la deshonra, y á las hijas en la vergüenza y la infamia (México I860, p.209).
Aquella tía ejemplar pintaba a la enferma con los colores más vivos la desesperación de las innumerables familias de provincias arruinadas por aquel abominable seductor $y$ corruptor de la juventud, que precipitaba a los hijos en los abismos del deshonor y de la miseria y arrastraba a las hijas a la perdicion $y$ a la infamia (1930, p.197).

This same strategy of translation is reproduced in the first Spanish translation by Pedro González-Blanco (r925?). On the one side, we notice that, the translation of "he is as odious» as "todo es vicio" [«verything is vicious"] is an indirect translation from the French "C'est toujours du vice»; on the other, that the translation of «spendthrift" as "tragón de herencias" [«inberitance glutton»] derives from «avaleur de tout bien». Through this manipulation of the source text George is not only characterized as an unscrupulous influence on young people, but also as the brother who steals the money from the Crawley estate:

'At least the money will remain in the family', she said, charitably. 'Pitt will never spend it, my dear, that is quite certain; for a greater miscr does not exist in England, and he is as odious, though in a different way, as his spendthrift brother, the abandoned Rawdon' $(V F, \mathrm{p} .396)$.

«Cet argent du moins ne sortira pas de la famille», disait cette charitable dame à son mari. «Vous pouvez bien être assuré que Pitt ne le dépensera jamais. L'Angleterre n'a jamais rien produit de plus ladre et de plus avare. C'est toujours du vice, bien que sous une autre forme que chez cet avaleur de tout bien, cet abominable Rawdon» (1853 II: p.91).

Este dinero al menos no saldrá de la familia, decía esta caritativa señora á su marido. Inglaterra no ha producido nada más tacaño y más avaro. Todo es vicio, aunque bajo dis- 
tinta forma, en este tragón de herencias, su hermano, el abominable Rawdon (I925?, p.216).

16
Gregorio Lafuerza (1930) deepens in the image of Rawdon Crawley as a fooled husband. Instead of the original epithet «dull», which lacks any kind of pejorative connotations, he adds three different adjectives, "estúpido, ciego y sordo" [ustupid, blind and deafs], that portrait the character as an indulgent gentleman aware of his wife's schemes:

Her husband was stupid certainly-all English are stupid- and, besides, a dull husband at Paris is always a point in a lady's favour $(V F, \mathrm{p} .384)$.

Claro está que su marido era un estúpido... todos los ingleses lo son... un estúpido, ciego y sordo, por añadidura, circunstancias todas éstas que, en París, lejos de hacer desmerecer a los maridos, avaloran su mérito (1930, p.35I).

In relation with Lord Steyne, the Spanish translations introduce lexical components linked in many cases to the French version, that render the main characteristics of Vanity Fair's villain more explicit. Both Georges Guiffrey (I853) and Pedro González-Blanco (1925?) use "orgies/orgies» instead of «banquets», emphasizing Lord Steyne's dimension as a pervert, which had only been hinted by William M. Thackeray's omniscient narrator, and presenting him to the target reader as someone with a dissipated sexual life:

In the pride of her beauty she had been married - sold, it was said- to Lord Gaunt, then at Paris, who won vast sums from the lady's brother at some of Phillip of Orleans's banquets $(V F, \mathrm{p} .466)$.

Dans tout l'éclat de sa beauté on l'avait mariée ou plutôt vendue à lord Gaunt qui, étant venu pour se distraire à Paris, avait gagné des sommes considérables au milieu des orgies auxquelles on se livrait dans le palais de Philippe-Egalité (1853, II: p. 177).

En todo el esplendor de su belleza la habian casado, ó mejor dicho, la habían vendido á lord Gaunt que habia venido para distracrse á París y había ganado considerables sumas en medio de las orgias á que se entregaba en el palacio de Felipe-Igualdad (I925?, p.256).

In a very similar rendering, Gregorio Lafuerza (I930), during the famous scene of the fight between Rawdon Crawley and Lord Steyne, includes the apposition "bailarina de costumbres más ligeras" [flippant ballet dancen], which rates the morality of Rebecca's mother very negatively. The adjective "complaciente" [ «indulgent"] is used to explain the apparent relation between the ex governess and the aristocrat as a scheme designed by both members of the married couple, and the noun «venado» [«deer»] to describe Rawdon Crawley to the Spanish readers as a cockhold:

You're as innocent as your mother, the ballet-girl, and your husband the bully. Don't think to frighten me as you have done others. Make way, sir, and let me pass" ( $V F$, p.533).

¡Tan inocente cres tú como tu madre, bailarina de costumbres más ligeras... tan inocente como tu marido, que viene ahora a alardear de dignidad, cuando de lo único que puede blasonar es de "complaciente"...! ¡Paso, señor venado... que a mi no me asustan los bravos! (I930, p.519).

\section{TRANSLATED TEXTS AND THE REWRITING OF FEMALE SEXUAL STEREOTYPES}

Maria DiBattista states that in Vanity Fair, as in Middlemarch, we find a disturbing description of basic social institutions such as marriage, and a sharp analysis of the changing role 
of women in English society. William M. Thackeray eperceives, but cannot totally disavow, the same corrupting sexual ideology, the wholesale selling and emotional victimization of women to ensure the traditional primacy and the economic power of an imperilled chaste» ${ }^{17}$. In Jenni Calder's opinion, the novels of Jane Austen are essential to understand Rebecca Sharp, probably the author's most sophisticated creature, who will do anything to ensure herself economic security through a marriage that will be above all «a union of families, often financially strategic, a union with all kinds of social implications, bringing in it weak elevations and descents, gains and losses, property and mothers-in-law, ${ }^{\mathrm{r}}$.

In Vanity Fair the lives of Rebecca and Amelia, two women who have been educated to get married, are contrasted. On one side, Amelia is the embodiment and main victim of all the values of an education fostered by her parents; on the other, Rebecca Sharp is a young girl, who must content herself working as a governess, the only honest job allowed to young poor women in Victorian fiction. She challenges this strict social system in her search for the advantages of a comfortable marriage which would enhance her position in society. In both cases, their marriages will be an absolute disaster. As a matter of fact, love, as an emotional experience, disappears from Vanity Fair to be transformed into a product that can be bought and sold in the marriage market.

The mediation of the French text (1853) can be traced in many of the samples that have been analysed. However, regarding Amelia Sedley, both Pedro González-Blanco (1925?) and Gregorio Lafuerza (I930) reproduce and make even more explicit those features that

17 DiBattistal, M. «The Triumph of Clytemnestra: The Charades in Vanity Filir", PMI.A, 95 (1980) pp.827-37.

is Cilder, J. Wonen and Marriage in Victorian Fiction. London: Thames \& Hudson, 1976 . identify her with the prototype of the submissive wife and with the personification of virginal purity. The following lines from the first Spanish translation that describe Amelia Sedley as a weak and forsaken woman are an excellent illustration of the ideological manipulation related to this character:

¡Débil y sensible criatura, tú no estás hecha para el tumulto y las luchas de este mundo de vanidades! (I925?, p.265).

[Weak and sensitive creature, your bave not been created for the struggles and toils of this world of vanities!]

Pedro González-Blanco (1925?), Gregorio Lafuerza (1930) and the French version (1853) line up reproducing misogynist cultural stereotypes when they translate "poor wretch" (referring to Rebecca Sharp) as upauvre créature souillée/ ipobre criatura manchada!» ["poor tarnished creature»]. They also insert the word "saintes/santos" [ «saints»] to designate Amelia's caresses and kisses. Similarly, Gregorio Lafuerza (1930) rewrites part of the source text and conveys the image of Amelia Sedley as a submissive, unreal woman through the following words of her husband, George Osborne: "queridita mía»[ [my darling»], «mi cielo» [«my angel»] y «mi idolo» [«my idol»]:

'Ycs, I shall make my way as well as anothcr', Osborne went on; 'but you, my dear girl, how can I bear your being deprived of the comforts and station in society which my wife had a right to expect? My dearest girl in barracks; the wife of a soldier in a marching regiment; subject to all sorts of annoyance and privation? It makes me miserable' $(V F$, p.247).

Repito que mi sucrte no me asusta, pero tú... queridita mía. ¿̨cómo has de resignarte a renunciar a la vida y al puesto que mi esposa 
tiene derecho a ocupar en sociedad? ¡Mi mujercita adorada en un cuartel...! ¡Mi cielo casada con un militar que acaso haya de ir a la guerra...! ¡Mi idolo cxpuesto a toda clase de desventuras y privaciones...! ¡Me desespera pensarlo! (I930, p.252).

Barbara Hardy believes that Amelia's love for George is wunreal and inactive, composed of the response to a social stereotype of masculine charm»"In this sense, Gregorio Lafuerza (I930) adds certain expressions, such as "amado de mi alma" [ "love of my soul»] y "amor tan intenso y puro» ["love so strong and pure»], that in this translation produce the effect of idealising the character of George Osborne. At the same time, the Mexican translator (I860) and Gregorio Lafuerza (1930) legitimate Amelia's marriage, while Rebecca Sharp is called «alma falaz, esposa infiel» [«deceitful soul, unfaithful wife»] (1860) y «esposa infiel y criminal» ["riminal, unfaitbful wife»] (1930).

Related to the ideological rewriting that the Hispanic translations make of Amelia Sedley, a parallel textual manipulation is traced in the case of Rebecca Sharp. The translated texts, under the close influence of the French version (I853), remove Thackeray's calculated ambiguity in order to encourage controversial aspects bound up to this character along Vanity Fair. Among these we would highlight those texts that describe Rebecca as a cynical woman, an unfaithful wife and a bad mother.

Gregorio Lafuerza (1930), in an idelogical turn that is spread throughout his text, adds the sentence «la compañía de maridos complacientes» [ «the company of indulgent busbandss], a clear allusion to Rawdon as a deceited husband. The same strategy of translation is noticed in the addition of another sentence, «la debilidad de su mujercita» [«the weakness of bis

11) Hardy, B. Forms of Feeling in Victorian Fiction. London: Peter Owen, I985. little wife»], which designates what seems to be Rebecca's constant urgency to fool her husband.

D.A. Thomas ${ }^{20}$ defines Vanity Fair as a world of predators. In his opinion, William $M$. Thackeray makes his readers perceive that Amelia shows an extreme submission in her relationship with other people, while Rebecca hides her social ambition and extreme urge to enslave male characters behind a hypocritical submissiveness. In the first Spanish translation (r925?), we find the addition of the sentence "Por algo ha tomado de ayudante al marido» ["That is why be has taken the husband as bis assistant»], that, not being part of the source text nor of the French version (1853), contributes emphasizing the role of Rebecca as an unscrupulous wife ready to sell her body to her husband's general.

The strong ideological manipulation perceived in the French version (1853) is transmitted onto the three first Hispanic translations of Vanity Fair through the mechanisms of indirect translation. In this case, the French rendering, "Voulez-vous dîner avec moi ce soir?», is much more explicit than its original English source text, «Will you dine here?». Following this strategy, the Hispanic translations, "Quiere usted comer conmigo?» [ Would you like to eat with me? "], transform the veiled allusion to Rebecca's meal with George Osborne into a straight invitation that makes their affair more explicit to Spanish readers. Finally, the addition of the sentence, "Te suis toute seule» [ II am alone»], which is added by Georges Guiffrey (1853) and also reproduced by the Mexican translator (1860) and Pedro González-Blanco (I925?) completes the rewriting of the source text:

'Will you dine here? The dragon dines with the Commander-in-Chief. Great news

so Thomas, D.A. Thackeray and Slavery. Athens: Ohio UP, 1993. 
is stirring. They say the French have crossed the frontier. We shall have a quiet dinner' $(V F$, p.287).

Voulez-vous dîner avec moi ce soir? Je suis toute seule. Mes deux dragons dinent chez le général en chef. Au fait, vous savez les grandes nouvelles? Les Français ont, dit-on, passé la frontière. Nous dînerons bien paisiblement (1853 I: p.342).

- ¿Queréis comer conmigo? Hoy estoy sola. Mis dos dragones comen en casa del general en gefe [sic]. Pero ¿no sabéis la noticia que corre? Parece ser que los franceses han pasado la frontera. Comeremos en paz octaviana (186o, p.328).

- Quiere usted comer conmigo esta noche?- dijo Rebecca a Jorge. Estoy sola ... Comeremos muy á gusto (I925?, p. I59).

- ¿Quiere usted comer conmigo? Mi dragón come hoy con el general... Han llegado noticias sensacionales... Parece que los franceses han cruzado la frontera... Será una comida tranquila... en familia (1930, p.389).

The ambiguous relationship between Lord Steyne and Rebecca is also portrayed in a similar way by Gregorio Lafuerza (1930). In this case, there is a different kind of physical contact between the characters. If William M. Thackeray only allows the villain to kiss her hand, in the second Spanish translation he is about to «dar un beso a la dama" [«to kiss the lady"].

In this part of the novel, Pedro GonzálezBlanco (1925?) adds the following paragraph, that is neither in Vanity Fair, nor in the French version ( 1853 ), in which the ex governess cynically plans her future existence if her husband was to die in the battle of Waterloo: «Quién podría afirmar que ésta no pensaba, en caso de verse viuda, en llegar á conquistar al general de su marido y decorarse con un título de duque- sa?" [ "In the case of becoming a widow, who could say that she bad not thought about conquering ber busband's general and dress berself with the title of duchess"].

If William M. Thackeray conceived Rawdon Crawley as a loving father, positively changed by parenthood, his wife, Rebecca Sharp, will never be able to love her son. This feature, censured by the most conservative critics and readers of the novel, is underlined by the two Spanish translations. Hence, Gregorio Lafuerza (I930), in a passage in which she violently hits her son Rawdy, translates «struck him violently a couple of boxes on the ear" as «le propinó media docena de soberbios bofetones» [ «she gave bim balf a dozen of magnificent slaps»]. This picture of Rebecca as a violent mother can also be found in Pedro GonzálezBlanco (I925?). However, as a consequence of the vast macrostructural bowdlerization of the first Spanish translation, this text appears in chapter LII. This time, the translator underlines Rebecca's guiltiness through the addition of three sentences: «el chiquillo estorbaba al marqués" [ «the lad was a bindrance to the marquis"], "los largos encierros que ambos tenían cuando el coronel estaba ausente» [ «the long retreats they both bad when the colonel was away"] and "el sendero extraviado en el cual se perdia» (p.23o) [ «the wrong path in which she lost her way"], a path which according to Gregorio Lafuerza (I930) will lead her to mix with «la hez de la sociedad» (p.636) [«the dregs of society"].

\section{CONCLUSIONS}

t. Theoretical and prescriptive models of translation together with descriptive approaches to the study of translated literature must involve "the juxtaposition of source and target texts, their comparison and the painstaking analysis of findings present in the context of the changing relations between the cultures 
involved ${ }^{22}$. Furthermore, research in norms of translations must be completed by the contextualization of foreign literature in national polysystems.

2. The mediating role of French translators in Spanish versions of English literature during the eighteenth and nineteenth century is an intercultural phenomenon acknowledged by different scholars, but only documented to a certain point. Vanity Fair's translations of I930 and 1943 still show a clear influence of French source texts in the Spanish publishing market. Systematic research should offer more detailed information about the chronological development of indirect translations in the twentieth century. Even nowadays, it is possible to find indirect versions in cheap paperback editions of English classics.

However, two important factors introduced changes in the Spanish publishing industry after World War II: first, the growing prestige of English-speaking culture and the overwhelming influence of the United States increased the number of people who studied English and, in consequence, that of translators who could render direct versions; second, Spanish readers would eventually demand reading direct translations from original versions and, therefore, publishing houses would advertise it as one of their marketing strategies.

3. The early version of Vanity Fair in Mexico (I860) opens another interesting field of research in relation with the translation of foreign literature in Latin American countries after their independence from Spain. If French cultural predominance is quite clear at that time, the influence of translated texts in the complex development of their national literatures still needs to be described through extensive surveys.

4. The ideological manipulation of sexual

"Von lilotow, L. Translation and Gender (Trans)ating in the 'Era of Feminism'). Manchester: St. Jerome-University of Ottawa l'ress, 1997, p. 19. stereotypes described in early French and Hispanic versions of William M. Thackeray's Vanity Fair illustrates the fact "that the foundational relation between a translation and its source text is not one of equivalence, but of interpretative resemblance (...) there simply is no fixed translation-theoretic norm of equivalence that one needs to fulfil in order to produce a 'good' translation»'. Although many readers have no access to the original novels, and most publishing houses still prefer to preserve the illusion of transparency, the translator's voice can be detected through his/her interpretative use of language, especially in the case of complex, allusive source texts.

RECIBIDO EN DICIEMBRE DE 2000

\section{REFERENCES}

Botrel, Jean-François (1993). Libros, Prensa y Lectura en la España del siglo XIX. Translated by David Torra Ferrer. Madrid: Fundación Germán Sánchez Ruipérez-Ediciones Pirámide.

Calder, Jenni (1976). Women and Marriage in Victorian Fiction. London: Thames \& Hudson.

Clarke, Micacl M (I995). Thackeray and Women. Dekalb: Northern Illinois University Press.

DiBattista, Maria (I980). "The Triumph of Clytemnestra: The Charades in Vanity Fair', PMLA, 95, 827-37.

Escolar, Hipólito (1999). Gentes del libro. Autores, Editores y Bibliotecarios I939-I999. Madrid: Gredos.

Gaddis Rose, Marilyn (1997). Translation and Literary Criticism. Translation as Analysis. Manchester: St. Jerome.

Gutt, Ernst-August (I996). «Implicit Information in Literary Translation", Target, 8:2, 239-256.

Hardy, Barbara (1985). Forms of Feeling in Victorian Fiction. London: Peter Owen.

Hatim Basil \& Ian Mason (1997). The Translator as

23 Gutt, E.A. «Implicit Information in Literary Criticism. Translation as Analysis», Target, 8:2, (1996) p.252. 
Cómmunicator. London: Routledge.

Hermans, Theo (1996). “The Translator's Voice in Translated Narrative», Target, 8:I, 23-48.

Kittel, Harald \& Armin Paul Frank (eds.) (Ig9r). Interculturality and the Historical Study of Literary Translations. Berlin: Erich Schmidt.

Martínez, José Luis (1986). El libro en Hispanoamérica. Origen y desarrollo. Madrid: Fundación Germán Sánchez Ruipérez-Ediciones Pirámide.

Montesinos, José (I960). Introducción a una bistoria de la novela en España en el siglo XIX. (Seguido del esbozo de una bibliografia española de traducciones de novelas $1800-1850$ ). Madrid: Castalia.

Simon, Sherry. Gender in Translation. Cultural Identity and the Poetics of Transmission. London: Routledge, I996.

Thackeray, William M. (1994). Vanity Fair (A Novet without a Hero). Peter L. Shillingsburg (cd.). New York: W.W. Norton.

- (1853) La foire aux vanités. Translated by Georges Guiffrey. Paris: Hachette.
(I860) La feria de las vanidades. México: Imprenta de Andrade y Escalante.

(1925?) La feria de las vanidades. Translated by Pedro González-Blanco. Madrid: La Novela Ilustrada.

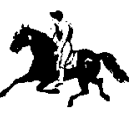

- (r930) La ferta de las vanidades (Uni novela sin beroe). Translated by Gregorio Lafuerza. Barcelona: Sopena.

Thomas, D.A. (I993). Thackeray and Slavery. Athens: Ohio UP.

Vapereau, M (1880). Dictionnaire Universel des Contemporains. Paris: Hachette.

Venuti, Lawrence (I995). The Translator's Invisibility. London \& New York: Routledge.

Von Flotow, Luise (1997). Translation and Gender (Translating in the 'Era of Feminism'). Manchester: St. Jerome-University of Ottawa Press.

VV.AA. Diccionario Enciclopédico de México, 1989. 